\title{
Exploring the energy performance of an existing industrial building
}

\author{
Sokol Dervishi ${ }^{*}$, Sikris Karamani \\ Department of Architecture, Epoka University, Rruga Tiranë-Rinas, Km 12, 1039, Tirana, Albania
}

\begin{abstract}
The present paper explores the energy performance and thermal comfort conditions of an existing industrial building in Durres, Albania. The study analysis the building envelope retrofitting via building performance simulation. Measurements of indoor air temperature in two zones of the building were conducted Two retrofit scenarios were applied to evaluate the potential for improvement. Detailed construction activity, weather information, and occupancy patterns were applied in modelling the facility. In addition, detailed interior loads were considered including the machines used, occupancy and lighting operation patterns. The results provide an objective assessment of the actual energy performance and indoor environmental performance of the selected industrial building. The scenarios incorporate the use of thermal insulation of the walls and the roof, as well as modifying the roof design while increasing the ventilation regime during the summer period. The results suggest that improvements and insulations in building fabrics and ventilation regime could reduce the annual energy consumption up to 19 and reduce the monthly summer temperature up to $1.5^{\circ} \mathrm{C}$.
\end{abstract}

\section{Introduction}

The building construction and their operation contribute to a large proportion of total energy end-use worldwide $[1,2]$. Existing buildings are consuming most of the energy in the building sector. As such, rapid enhancement of energy efficiency in existing buildings is crucial for the reduction of the energy use and promotion of environmental sustainability. The industrial buildings are consuming more than $25 \%$ of the total energy consumption in Europe [3]. Production facilities highly increase the energy use in buildings. Codes on energy performance evaluation by the national legislation needs to be strengthen [4], and the adoption of ISO 50001 standard on energy management systems is being promoted.

As such, thermal refurbishment and renovation of the building envelope is crucial to improve the overall energy consumption [5]. Building energy simulation (BES), are being applied in the early design stages to estimate the energy saving measures [6]. In a retrofit context, BES is used to simulate the existing condition of the buildings, serving as a baseline for potential simulated retrofit solutions, evaluate energy savings, and assess thermal comfort [7, 8, 9]. A significant amount of research investigated different energy efficiency retrofitting measures in order to improve energy performance of existing buildings [10] mainly in residential and public sector. The results have showed that energy use in existing buildings can be reduced significantly through proper retrofitting or refurbishment $[11,12]$.

Different authors have worked on the development and application of appropriate models and strategies for building performance assessment and diagnostics. [13] summarised three approaches to evaluating building energy performance, performance based approach and measurement-based approach with in situ measurement procedures. [14] explored an overview of the simulation models used for energy performance analysis of existing dwellings. [15] developed an application of model identification techniques for energy performance assessment of occupied buildings. [16] studied an easyto-use tool for fault detection and diagnosis of building air-conditioning systems.

On the other hand, Industrial facilities are rarely studied under an energy retrofit measures [17], focusing on building envelope [18] or on installed technical building services when these are identified as inefficient, e.g. heating [19], ventilation [20]. Industrial heritage has also been studied under an energy retrofit perspective, however mostly concerning ex-industrial facilities and their transformation to other uses as housing or mixeduse developments [21].

\section{Methodology}

The study explores the energy performance evaluation of a case study in Durres, Albania. The climate is mild, warm and temperate. The temperature averages $15.9^{\circ} \mathrm{C}$. At an average temperature of $23.9{ }^{\circ} \mathrm{C}$, August is the hottest month of the year. In January, the average temperature is $8.1{ }^{\circ} \mathrm{C}$. METEONORM 7.0 [22], is used to provide the detailed hourly weather file. The annual energy consumption of the facility including heating and cooling is monthly calculated and aggregated on annual level. In addition, the hourly indoor air temperature is calculated and aggregated on monthly level.

Corresponding author: sdervishi@epoka.edu.al 
Assumptions of the internal gains due to manufacturing process are taken into consideration.

\subsection{The case study}

For the case study, an existing 'single-story industrial facility located in Durres, Albania is selected (see figure 1). The facility is operating in the sector of metal production and processing, categorized as light manufacturing industry. The building measures a gross floor area of about $20450 \mathrm{~m}^{2}$ and composed of five functional areas dedicated to a specific processes of the manufacturing activity (see Table 1 and Figures 2 to 3 ). The building is $13 \mathrm{~m}$ high, composed of steel structure. Both the walls and the roof are made of sandwich panels. The windows are placed only at the roof area.

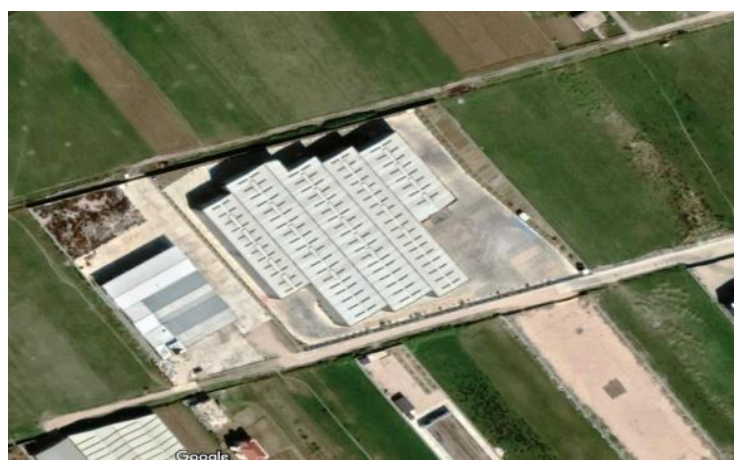

Fig. 1. Setting Word's margins.

Table 1. Functional areas of the building

\begin{tabular}{|c|c|c|}
\hline Area & Function & $\begin{array}{c}\text { Surface } \\
\text { Area }\left(\mathrm{m}^{2}\right)\end{array}$ \\
\hline 1 & Row material warehouse & 1390 \\
\hline 2 & Production and manufacture & 7710 \\
\hline 3 & Final product warehouse & 1050 \\
\hline 4 & Offices & 150 \\
\hline 5 & Shop & 150 \\
\hline
\end{tabular}

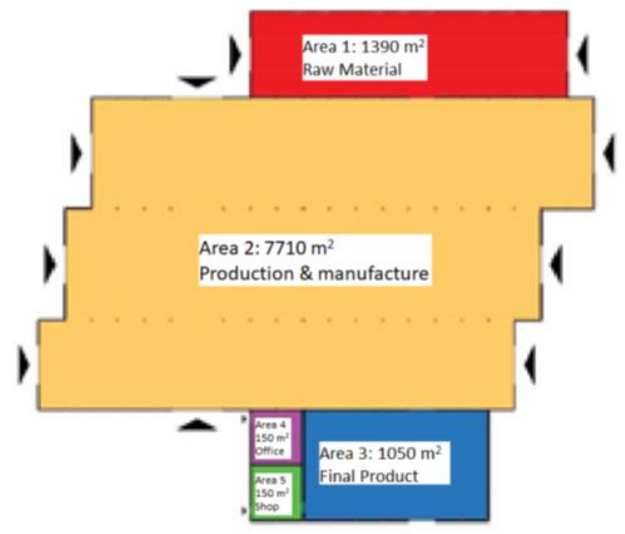

Fig. 2. Functional distribution of the building

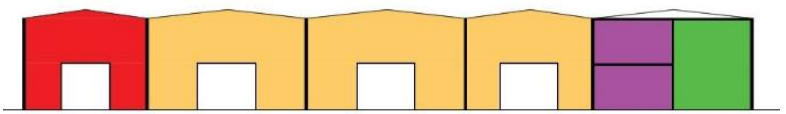

Fig. 3. Frontal sketching of the building

The building is oriented along the west-east axis. The space where most of the production occurs is a single extensive $8,760 \mathrm{~m}^{2}$ hall (Zone 02, Zone 03) spreading along the whole building, the rest are raw material warehouse, offices and shop areas. The factory is not naturally ventilated, no mechanical cooling system is installed in the production area. Furthermore, there are neither building automation systems nor an energy management and monitoring system installed.

\subsection{Measurements}

Two sensors are placed in two different areas of the buildings (Sensor 1 in the Production and Manufacturing area and Sensor 2 in the office building, respectively). The indoor air temperatures $\left({ }^{\circ} \mathrm{C}\right)$ are measured for seven days (10 April - 17 April, 2019). Figure 4 illustrates the registered temperatures in the two areas. As shown in the figures, the minimum temperature registered in the office area for a week is $17.5^{\circ} \mathrm{C}$ while the maximum temperature is $25.2^{\circ} \mathrm{C}$. As for the production area, the minimum registered temperature is $12.3^{\circ} \mathrm{C}$ and the maximum temperature is $23.2^{\circ} \mathrm{C}$.

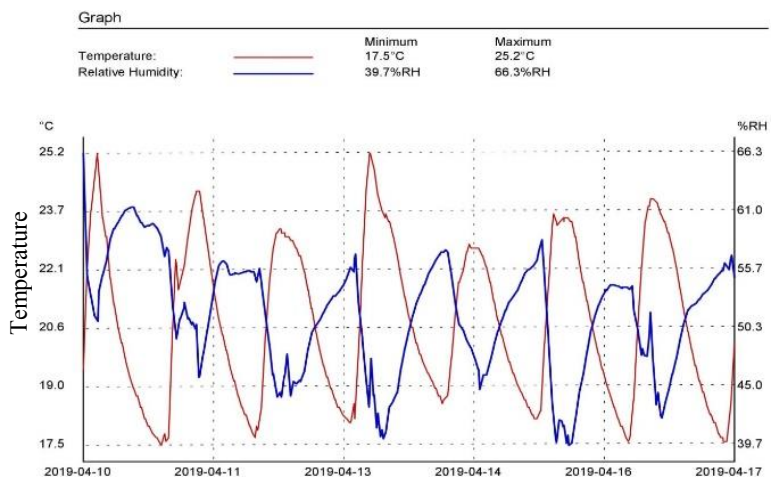

Fig. 4. Measured indoor air temperature $\left({ }^{\circ} \mathrm{C}\right)$ in the office area (Zone 04) for seven days (10 April - 17 April, 2019)

\subsection{Simulation}

Simulations were conducted for the case study over a period of one year. The whole building is modelled to analyse its effects on the total energy performance. The collected geometry and the construction data are used to generate the base case simulation model. Assumptions are made based on site surveying, documentation, and questionnaires. Simulation assumptions regarding actual construction data are summarized in Table 2. Based gathered information, detailed thermal performance simulation models were generated via Design Builder software [23] (see figure 5). Input parameters used for the 
simulation are based on the analysing the facility in terms of occupancy schedules, manufacturing operating times and building systems availability (lighting and heating). There is no adequate mechanical heating and cooling system. Table 2 illustrates the heating and cooling set up temperatures taken into consideration.

Table 1. Actual building elements U-values

\begin{tabular}{ccc}
\hline $\begin{array}{c}\text { Building } \\
\text { elements }\end{array}$ & $\begin{array}{c}\mathrm{U} \text { value } \\
\left(\mathrm{W} / \mathrm{m}^{2} \mathrm{~K}\right)\end{array}$ & Description \\
\hline External wall & 0.81 & $\begin{array}{c}\text { Sandwich panel (tin, } \\
\text { polystyrene } 4 \mathrm{~cm}+\text { tin }) \\
\text { Sandwich panel (tin, } \\
\text { polystyrene } 4 \mathrm{~cm}+\text { tin })\end{array}$ \\
$\begin{array}{c}\text { Glazing Area } \\
\text { Ground floor }\end{array}$ & 0.81 & $\begin{array}{c}\text { Single Glazing }(6 \mathrm{~mm}) \\
\text { Reinforced concrete }(25 \mathrm{~cm}), \\
\text { EPS insulation }(10 \mathrm{~cm}), \\
\text { screed }(7 \mathrm{~cm})\end{array}$ \\
\hline
\end{tabular}

Table 2. Temperature set-points

\begin{tabular}{cc}
\hline Temperature set point & Value \\
\hline Heating set-point factory $\left({ }^{\circ} \mathrm{C}\right)$ & 18 \\
Heating set-point factory set back & 12 \\
(night/weekend) $\left({ }^{\circ} \mathrm{C}\right)$ & \\
Cooling set-point factory $\left({ }^{\circ} \mathrm{C}\right)$ & 25 \\
Cooling set-point factory set back & 27 \\
(night/weekend) $\left({ }^{\circ} \mathrm{C}\right.$ ) & \\
\hline
\end{tabular}

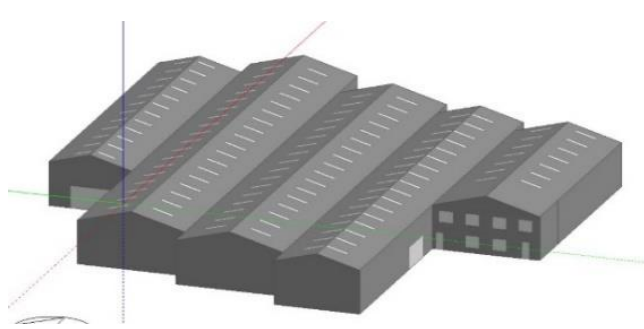

Fig. 5. Geometry of the industrial building modelled with design builder energy software

\subsection{Retrofitting scenarios}

Two retrofitting scenarios are proposed for the selected industrial building. Scenario 1 (S1) includes an improved $\mathrm{U}$ value of $0.45 \mathrm{~W} / \mathrm{m}^{2} \mathrm{~K}$ of the existing roof and walls (see table 2). Scenario 2 (S2), besides the improved insulation, replaces skylights while modifying their design (raised monitor roof) and increasing the ventilation regime during the summer period. Figure 6 and Figure 7 illustrate the existing and modified roof design of the facility.

Table 2. Proposed building elements U-values

\begin{tabular}{ccc}
\hline $\begin{array}{c}\text { Building } \\
\text { elements }\end{array}$ & $\begin{array}{c}\mathrm{U} \text { value } \\
\left(\mathrm{W} . \mathrm{m}^{-2} \mathrm{~K}\right)\end{array}$ & Description \\
\hline External wall & 0.45 & $\begin{array}{c}\text { Sandwich panel (tin, } \\
\text { polystyrene } 80 \mathrm{~mm}+\text { tin) } \\
\text { Sandwich panel }(\mathrm{tin}, \\
\text { polystyrene 40mm }+ \text { tin) }\end{array}$ \\
\hline
\end{tabular}

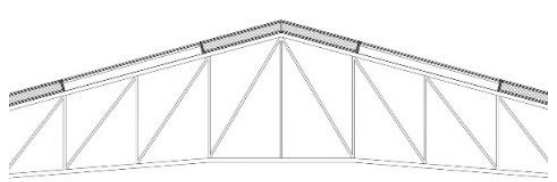

Fig. 1. Existing skylight design

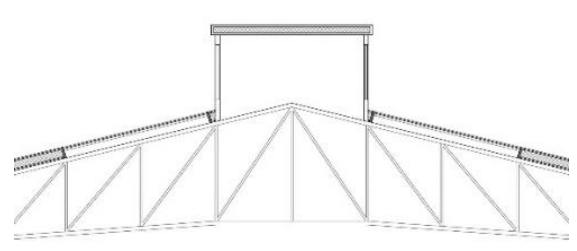

Fig. 2. Proposed skylight with altered roof to ameliorate ventilation

\section{Results and Discussion}

This section presents and discusses simulation results for cooling, heating and total monthly and annual energy demand and monthly indoor air temperature for basic case and optimization scenarios.

\subsection{Energy performance}

Figure 8 to 10 show the existing energy demand and retrofitting scenarios of the industrial building. Figure 8 presents the predicted monthly energy demand of the base case. Figure 9 compares the annual energy demand for heating and cooling of basic case and the tworefurbishment scenarios, S1 and S2 respectively. Figure 10 compares the energy demand for total annual energy demand of basic case and the two-refurbishment scenarios, S1 and S2 respectively. Both refurbishment scenarios are performing better than the base case with the cooling and heating energy demand. Cooling annual energy demand is reduced from $89.1 \mathrm{KW} . \mathrm{m}^{-2} \mathrm{y}^{-1}$ to 81.6 KW. $\mathrm{m}^{-2} \mathrm{y}^{-1}$ and $76.5 \mathrm{KW} . \mathrm{m}^{-2} \mathrm{y}^{-1}$ for $\mathrm{S} 1$ and $\mathrm{S} 2$ respectively, thus by $8 \%$ and $14 \%$. Annual heating energy demand is reduced from $37.5 \mathrm{KW} . \mathrm{m}^{-2} \mathrm{y}^{-1}$ to $32.6 \mathrm{KW} \cdot \mathrm{m}^{-2} \mathrm{y}^{-1}$ and 30.3 $\mathrm{KW} \cdot \mathrm{m}^{-2} \mathrm{y}^{-1}$ for $\mathrm{S} 1$ and $\mathrm{S} 2$ respectively, thus by $13 \%$ and $19 \%$. While, total annual energy demand (see figure 10 ) is reduced from $126.6 \mathrm{KW} . \mathrm{m}^{-2} \mathrm{y}^{-1}$ to $114.2 \mathrm{KW} \cdot \mathrm{m}^{-2} \mathrm{y}^{-1}$ and $106.8 \mathrm{KW} \cdot \mathrm{m}^{-2} \mathrm{y}^{-1}$ for $\mathrm{S} 1$ and $\mathrm{S} 2$ respectively, thus by $10 \%$ and $16 \%$. 


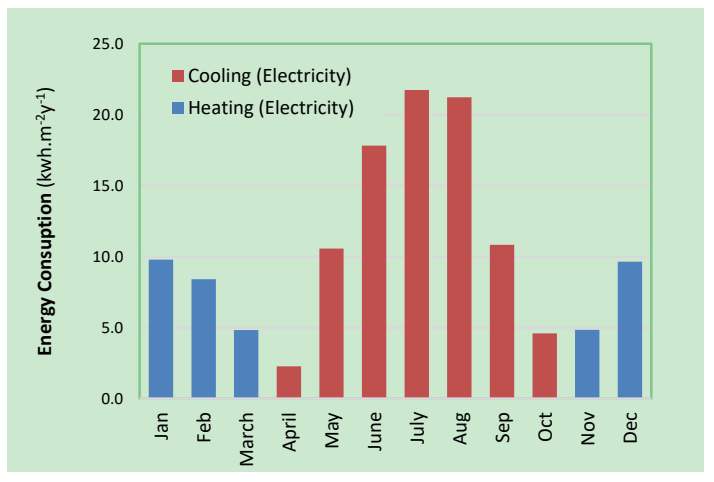

Fig. 3. Comparison of monthly cooling and heating energy loads for the base case (BC) of industrial building.

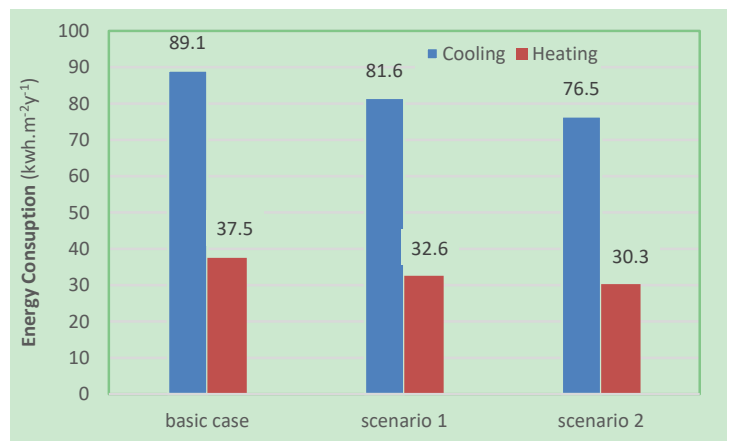

Fig. 4. Comparison of yearly cooling and heating energy loads for the base case (BC), scenario 1 and scenario 2 of industrial building.

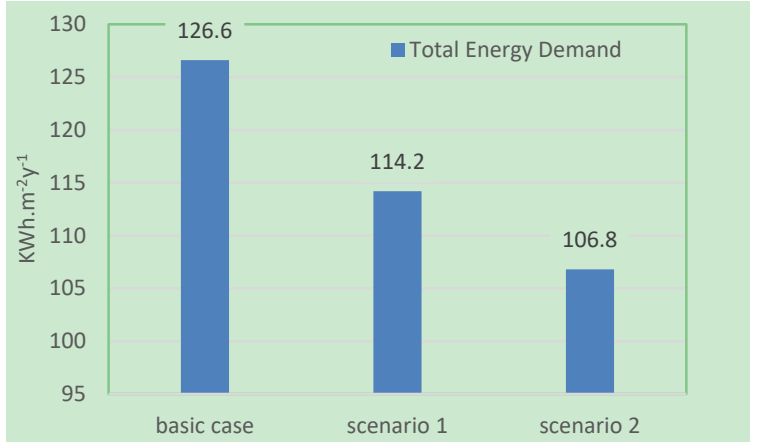

Fig. 5. Comparison of yearly total energy loads for the base case (BC), scenario 1 (S1) and scenario 2 (S2) of industrial building.

\subsection{Indoor thermal conditions}

Figure 11 illustrates the monthly indoor air temperature values for each zone of facility. Zone 1, Zone 2 and Zone 3 (see table 1) have lower air temperature, while Zone 4 and 5 have the highest temperatures. For instance, in January the monthly temperature difference of Zone 1, Zone 2, and Zone 03 compared to Zone 4 and Zone 5 is $5{ }^{\circ} \mathrm{C}$, while in July, the monthly temperature difference is $3{ }^{\circ} \mathrm{C}$. Figure 12 to figure 14 illustrate the indoor air temperature of each zone of the facility of basic case and the two-refurbishment scenarios (S1 and S2). Optimization scenario (S ) shows a reduction of $1{ }^{\circ} \mathrm{C}$ $1.5^{\circ} \mathrm{C}$ of Zone 1 , Zone 2 and Zone 3 for June, July, and August.

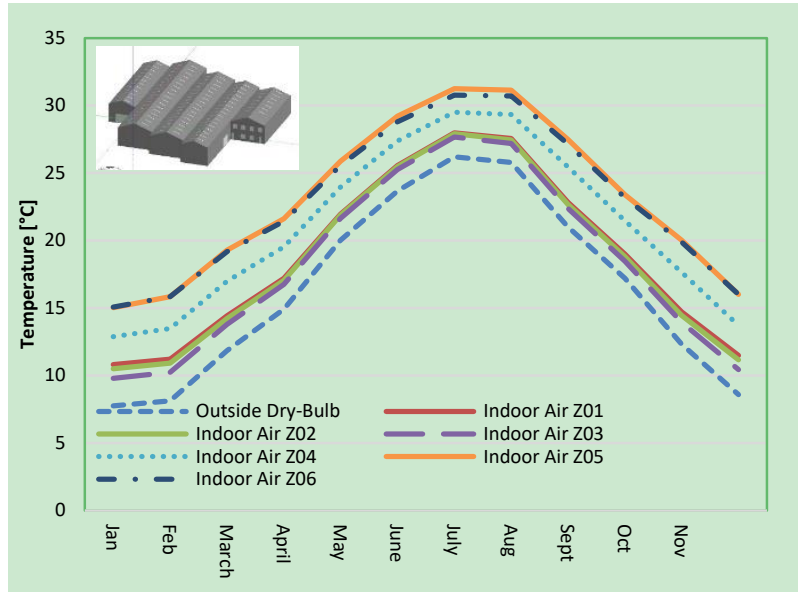

Fig. 6. Computed monthly indoor air temperature (for five zones) of the base case scenario and measured outdoor temperature

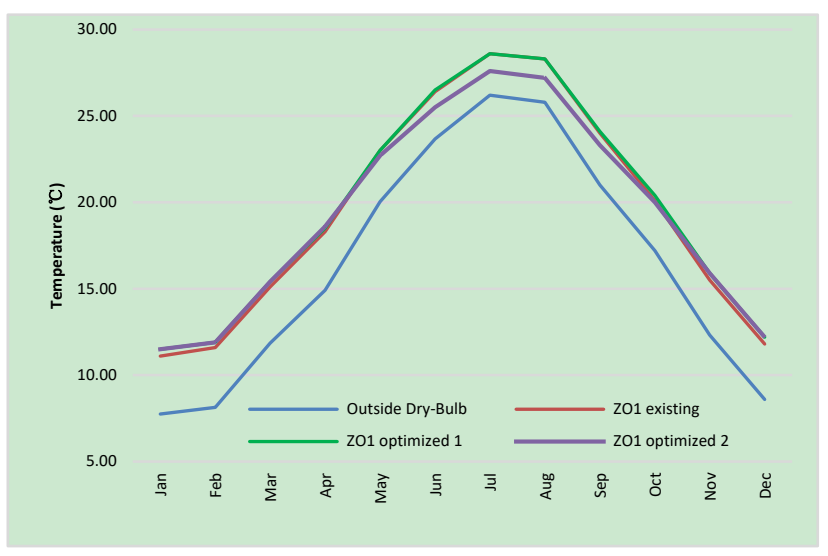

Fig. 7. Computed monthly indoor air temperature (for Zone 01) of the base case (BC), and improved scenarios (SC 01, SC 02) versus measured outdoor temperature

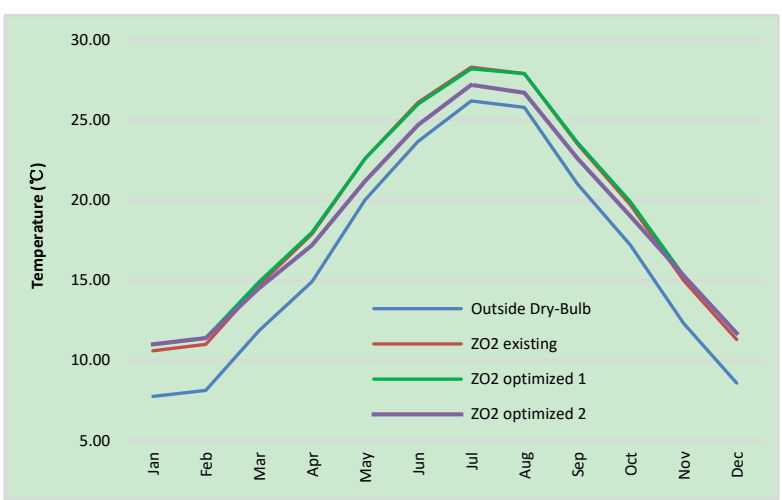

Fig. 8. Computed monthly indoor air temperature (for Zone 02) of the base case (BC), and improved scenarios (SC 01, SC 02) versus measured outdoor temperature 


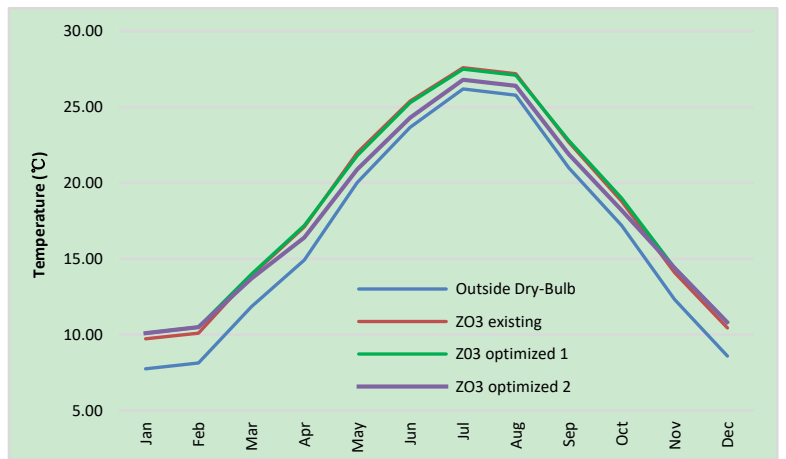

Fig. 9. Computed monthly indoor air temperature (for Zone 03) of the base case (BC), and improved scenarios (SC 01, SC 02) versus measured outdoor temperature

\section{Conclusion}

The paper presents a study on the energy performance evaluation and indoor thermal comfort of an industrial building in Durres, Albania. In order to analyse the thermal performance of the selected typologies and predict the consequences of alternative thermal retrofit measures, computational simulation model was used. In addition, the study explores the consequences of alternative thermal retrofit measures by using different scenarios. Certain combinations of improvement measures (e.g. insulations of walls, roof, and the use increased ventilation via alternative roof design) could improve the thermal performance of the buildings. The impact of the insulation in building fabric has significantly reduced the energy consumption up to $10 \%$. Replacement of roof design with increased daylighting and ventilation regime reduced the energy consumption up to $19 \%$.

\section{Reference}

1. E. Asadi, M.G. Silva, C.H. Antunes, L. Dias, Multiobjective optimization for building retrofit strategies: a model and an application, Energy and Buildings 41 (2012) 81-87.

2. DOE, Buildings Energy Data Book, Office of Energy Efficiency and Renewable Energy, U.S. Department of Energy, Washington, DC, USA (2010).

3. Eurostat. Final energy consumption, EU-28, 2012. $<$ ec.europa.eu/eurostat/statisticsexplained/index.php/Consumption_of_energy>

4. European Union. Directive 2010/31/EU of the European parliament and the council of 19 May 2010 on the energy performance of buildings. Off $\mathrm{J}$ Eur Union 2010;L 153:13-35.

5. T Hong, C Koo , J Kim, M Lee, K Jeong. A review on sustainable construction management strategies for monitoring, diagnosing, and retrofitting the building's dynamic energy performance: focused on the operation and maintenance phase. Applied Energy 2015; 155:671-707.

6. C.H. Baek, S.H. Park, Changes in renovation policies in the era of sustainability, Energy and Buildings 47
(2012) 485-496. Australian firms, Energy Policy 28 (2000) 867-876.

7. P. Resuli, S Dervishi. Thermal performance of cultural heritage italian housing in Albania. In: Proceedings of the 6th International Building Physics Conference, IBPC 2015, Torino, pp. 753-758.

8. R. Belba, S. Dervishi. Thermal performance analysis of traditional housing in Albania. 7th International Building Physics Conference, IBPC2018, 2018, p : 1485 - 1490, Syracuse, NY, USA.

9. R. Brecani, S. Dervishi. Thermal and energy performance evaluation of underground bunkers: An adaptive reuse approach. Sustainable Cities and Society 46 (2019) 101444

10. F. Flourentzou, C.A. Roulet, Elaboration of retrofit scenarios, Energy and Buildings 34 (2002) 185-192.

11. F. Ardente, M. Beccali, M. Cellura, M. Mistretta, Energy and environmental benefits in public buildings as a result of retrofit actions, Renewable and Sustainable Energy Reviews 15 (2011) 460-470.

12. E. Kaleci, S. Dervishi. Implementation Challenges to the Adaptive Reuse of a Heritage Building in Tirana, Albania. In: Proceedings of the 2nd International Conference in Architecture and Urban Design Epoka University ICAUD 2014, pp. 1-10, Tirana, Albania.

13. V. Richalet, F.P. Neirac, F. Tellez, J. Marco, J.J. Bloem, HELP (house energy labelling procedure): methodology and present results, Energy and Buildings 33 (2001) 229-233.

14. B. Poel, G.V. Cruchten, C.A. Balaras, Energy performance assessment of existing dwellings, Energy and Buildings 39 (2007) 393-403.

15. O. Mejri, E.P.D. Barrio, N. Ghrab-Morcos, Energy performance assessment of occupied buildings using model identification techniques, Energy and Buildings 43 (2011) 285-299.

16. Y.H. Song, Y. Akashi, J.J. Yee, A development of easy-to-use tool for fault detection and diagnosis in building air-conditioning systems, Energy and Buildings 40 (2008) 71-82.

17. A Trianni, E Cagno, A De Donatis. A framework to characterize energy efficiency measures. Appl Energy 2014; 118:207-20.

18. J Katunska, J Oberleova, A Rusnak, S Toth. Diagnosis of elected industrial hall object and idea for its reconstruction. Adv. Mater Res 2014; 1057:19-26.

19. D. Chinese, G Nardin, O Saro . Multi-criteria analysis for the selection of space heating systems in an industrial building. Energy 2011; 36(1):556-65.

20. A.C. Caputo, P.M. Pelagagge. Upgrading mixed ventilation systems in industrial conditioning. Appl Therm Eng 2009; 29(14):3204-11.

21. Meteonorm n.d. http://www.meteonorm.com/

22. Design builder n.d. https://www.designbuilder.com /https://www.designbuilder.com/software/productoverview (Accessed February 2, 2018) 